\title{
ANTIOXIDANT AND ANTIMICROBIAL ACTIVITY OF A NEW GENERATION PHYTO-GEL
}

Dragan J. Cvetković1*, Ljiljana P. Stanojević1, Tatjana Kundaković ${ }^{2}$, Saša Ž. Zlatković1, Goran S. Nikolić ${ }^{1}$

${ }^{1}$ Faculty of Technology, University of Niš, Leskovac, Serbia

${ }^{2}$ Faculty of Pharmacy, University of Belgrade, Belgrade, Serbia

Antioxidant and antimicrobial activities of a new phyto-gel were studied in this work. The formulated gel is composed of propilene glycol extracts of St. John's worth $(H$. perforatum L.), comfrey (S. officinale L.), yarrow (A. millefolium L.), horsetail (E. arvense L.) and Na-usniate. The antioxidant activity was determined for the gel and each investigated extract of the gel separately by the DPPH test. The total phenols and flavonoids content was determined spectrophotometrically, for the gel and each investigated extracts. The antimicrobial activity of the gel and each compound separately was tested in vitro on the following microorganisms: Staphylococcus aureus, Micrococcus luteus, Bacillus subtilis, Escherichia coli, Klebsiella pneumoniae, Pseudomonas aeruginosa, Candida albicans and Aspergillus niger. The antioxidant activity of the investigated samples decreases in the series: $H$. perforatum $\left(E_{50}=1.04 \mathrm{mg} / \mathrm{mL}\right)$ $>$ Na-usniate $\left(E_{50}=4.16 \mathrm{mg} / \mathrm{mL}\right)>$ A. millefolium $\left(E C_{50}=7.60 \mathrm{mg} / \mathrm{mL}\right)>$ gel $\left(\mathrm{EC}_{50}=23.47 \mathrm{mg} / \mathrm{mL}\right)>$ S. officinale $\left(\mathrm{EC}_{50}=30.10 \mathrm{mg} / \mathrm{mL}\right)>E$. arvense $\left(\mathrm{EC}_{50}\right.$ $=44.70 \mathrm{mg} / \mathrm{mL}$ ). The formulated phyto-gel showed the antimicrobial activity. The results suggest that the obtained phyto-gel is a good source of natural antioxidants and antimicrobial agents, and it has potential as an alternative to synthetic products in pharmaceutical and cosmetic industries.
(ORIGINAL SCIENTIFIC PAPER) UDC 615.454.1:615.322

Keywords: antioxidant activity, antimicrobial activity, phyto-gel, plant extracts, $\mathrm{Na}$ usniate

\section{Introduction}

The plants with the antioxidant activity have drawn attention in recent years due to the development of a large number of different diseases $[1,2]$. It has been hypothesized that these diseases are caused by action of free radicals in most cases [3]. Antioxidants have the ability to inhibit the free radicals generation or to remove the already formed free radicals by their direct action [4]. There are a number of natural antioxidants, e.g. a-tocopherol [5]; ascorbic acid [6,7]; retinol, thiamin and riboflavin, flavonoids [8] and phenolic acids [5,9], as well as a number of synthetic antioxidants $[10,11]$. Synthetic antioxidants such as butylated hydroxyanisole (BHA) and butylated hydroxytoluene $(\mathrm{BHT})$ have a potentially harmful effect on human health, leading to various dysfunctions [10]. One of the most important trends in the food and pharmaceutical industry today is searching for natural antioxidants from the plant material.

Medicinal plants have been used for centuries as remedies for various diseases because they contain bioactivecomponents of a therapeutic value [11-14]. There is the increasing use of a traditional medicine as an alternative form for treating various diseases due to the resistance of microorganisms to the existing synthetic antibiotics $[13,15]$. A large number of studies investigate the antimicrobial activity of natural phenolic compounds from plants [1,16-19] in order to find new, natural antimicrobial agents.

Flavonoids are synthesized in plants in response to microbial infection. It is therefore not surprising that these compounds have in vitro antimicrobial activity against a wide range of microorganisms $[20,21]$. Some phenolic compounds, such as resveratrol, hydroxytyrosol, quercetin and many phenolic acids may inhibit many pathogenic microorganisms [22-24].

There is considerable interest in preventive and traditional medicine for the development of natural antioxidants and antimicrobial agents obtained from plants [12].

The antimicrobial and antioxidant activities of these plant extracts were tested before [1,25-28], as well as the antimicrobial and antioxidant activities of usnic acid and related compounds from lichens $[29,30]$.

The aim of our study was to determine antioxidative and antimicrobial properties of propylene glycol extracts of St. John's worth (Hypericum perforatum L.), comfrey (Symphytum officinale L.), yarrow (Achillea millefolium L.), horsetail (Equisetum arvense L.) and sodium-usniate in formulated phyto-gel. The investigated extracts contain polar substances - flavonoids and phenolcarboxylic acids $(H$. perforatum, A. millefolium, $E$. arvense), naphthodianthrones and phloroglucinols (H. perforatum), alantoin (S. officinale),

\footnotetext{
* Author address: Dragan Cvetković, University of Niš, Faculty of Technology,

Bulevar Oslobođenja 124, 16000 Leskovac, Serbia

E-mail: cvetkovic@tf.ni.ac.rs

The manuscript received: August, 03, 2015.

Paper accepted: August, 20, 2015.
} 
sesquiterpene lactones ( $A$. millefolium). The antioxidative activity was tested by DPPH test and the antimicrobial activity using agar-diffusion and a microdilution method.

\section{Materials and methods}

\section{Plant material}

The aerial parts of commercial samples of $H$. perforatum A. millefolium (Adonis, Soko Banja, Serbia), E. arvense and S. officinale (Bilje Borča, Belgrade, Serbia), were used for the investigation. Sodium usniate was from Zdravlje-Actavis, Serbia.

\section{Reagents and Chemicals}

Folin-Ciocalteu reagent, 2,2-diphenyl-1-picrylhydrazil (DPPH), gallic acid were obtained from Sigma (St. Louis, $\mathrm{MO}$ ), and rutin from Merck. Sodium carbonate, potasium acetate and aluminium chloride were purchased from Merck-Alkaloid (Skopje, FYR Macedonia). Methanol was from Zorka-Pharma (Šabac, Serbia). HPLC grade acetonitrile (Merck, Darmstadt, Germany) and filtered bidistilled water were used for HPLC analysis. All standard components for HPLC analysis of the extracts were of HPLC reagent grade. All other chemicals were of analytical reagent grade.

\section{Extraction method}

The grained aerial parts of $H$. perforatum, A. millefolium, $E$. arvense and $S$. officinale were extracted with propylene glycol $(1: 10 \mathrm{~m} / \mathrm{v})$ at room temperature.

\section{Preparation of new phyto-gel}

Phyto-gel was prepared by gelation $50 \mathrm{~g}$ of carboxymethilcellulose with propylene glycol extracts $(60 \%, \mathrm{v} / \mathrm{v})$ of S. officinale $(2 \mathrm{~g}), H$. perforatum $(4 \mathrm{~g})$, A. millefolium $(4 \mathrm{~g})$, E. arvense $(4 \mathrm{~g})$ and $0.5 \mathrm{~g}$ of Na-usniat.

\section{HPLC analysis}

HPLC separation was performed using the Agilent 1200 Series HPLC system, equipped with a G-1312A binary pump, a G-1328B injector (loop of $20 \mu \mathrm{l}$ ) and G1315B DAD detector. The column used was a ZORBAX Eclipse XDBC18 $(4.6 \times 250 \mathrm{~mm}, 5 \mu \mathrm{m})$ and operated at the temperature of $25^{\circ} \mathrm{C}$. A gradient elution was performed with the solvent A $\left(\mathrm{H}_{2} \mathrm{O}\right.$ and $\left.\mathrm{H}_{3} \mathrm{PO}_{4}, \mathrm{pH}=2.8\right)$ and $\mathrm{B}$ (acetonitrile) as follows: $20 \%$ B (5 min), 40\% B (5 min), $50 \%$ B (5 min), $70 \%$ $B(5 \mathrm{~min})$ at a flow rate of $0.8 \mathrm{ml} / \mathrm{min}$. The injection volume was $20 \mu \mathrm{l}$. The present compounds were determined on the basis of their retention times and UV spectra, and by direct comparison with available standards. The detection wavelength was $254 \mathrm{~nm}$.

\section{DPPH assay}

The capacity of a compound to scavenge free DPPH radicals was determined by DPPH test [8,31-35]. The investigated extracts, sodium usniate, and gel were dissolved in methanol and various concentrations were prepared (the concentration range: $0.032-2.0 \mathrm{mg} / \mathrm{ml}$ for $\mathrm{H}$. perforatum; $0.625-20.0 \mathrm{mg} / \mathrm{ml}$ for A. millefolium; $2.5-80.0 \mathrm{mg} / \mathrm{ml}$ for E. arvense; $0.82-80.0 \mathrm{mg} / \mathrm{ml}$ for S. officinale; $0.31-10$ $\mathrm{mg} / \mathrm{ml}$ for sodium usnate and $0.51-50.0 \mathrm{mg} / \mathrm{ml}$ for gel). A $1.0 \mathrm{ml}$ of methanolic solution of DPPH $(3 \times 10-4 \mathrm{~mol} / \mathrm{l})$ was added to $2.5 \mathrm{ml}$ of the sample and measured after $20 \mathrm{~min}$ utes of incubation at room temperature. The absorbance of the samples was measured on VARIAN UV-Vis Cary100 Conc. spectrophotometer. The capacity of free radicals scavenging was calculated as follows:

DPPH radicals scavenging capacity $(\%)=\left[1-\frac{\left(A_{S}-A_{B}\right)}{A_{C}}\right] \cdot 100$

where AS is absorbance of the sample at $517 \mathrm{~nm}$ (methanolic solution of the samples treated with DPPH radical solution), $A B$ is absorbance of blank at $517 \mathrm{~nm}$ (the methanol solution of the samples not treated with DPPH radical solution), and $A C$ is absorbance of control at $517 \mathrm{~nm}$ (methanolic solution of DPPH radical). A decrease of $50 \%$ of the initial DPPH concentration was defined as $\mathrm{EC}_{50}$. The $\mathrm{EC}_{50}$ value $(\mathrm{mg} / \mathrm{ml})$ was determined for all samples. BHT was used as a reference compound $\left(E_{50}=0.021 \mathrm{mg} / \mathrm{ml}\right)$.

Determination of total phenolic content

The total phenolic content in the investigated samples was determined spectrophotometrically according to the Folin-Ciocalteu method [36] using gallic acid (GAE) as a standard with small modifications [35]. The reaction mixture was prepared by mixing $1 \mathrm{ml}$ of the methanolic solution of the samples (concentration 100.0; 1.0; 12.6; 32.0; 100.0 and $95.0 \mathrm{mg} / \mathrm{ml}$ for gel; sodium usniate; extracts of $H$. perforatum, A. millefolium, E. arvense and S. officinale, respectively); $9 \mathrm{ml}$ of distilled water, $1 \mathrm{ml}$ of Folin-Ciocalteu's reagent and $10 \mathrm{ml}$ of $7 \%$ sodium carbonate. After the 90 minutes incubation at room temperature, the absorbance was determined spectrophotometrically at $765 \mathrm{~nm}$. The total phenolic content was expressed as GAE in milligram per gram of the dry extract [35].

\section{Determination of total flavonoids content}

The total flavonoids content was determined according to the aluminium chloride colorimetric method [37] with small modification [35]. Each sample $(2 \mathrm{ml}$, concentration of $100.0 ; 1.0 ; 12.6 ; 32.0 ; 100.0$ and $95.0 \mathrm{mg} / \mathrm{ml}$ for gel; sodium usnate; propylene glycol extracts of $H$. perforatum, $A$. millefolium, E. arvense and S. officinale, respectively) in methanol were mixed with $0.1 \mathrm{ml}$ of $10 \%$ aluminium chloride hexahydrate, $0.1 \mathrm{ml}$ of $1 \mathrm{M}$ potassium acetate and $2.8 \mathrm{ml}$ of deionized water. After 40 minutes of incubation at room temperature, the absorbance of the reaction mixture was determined spectrophotometrically at $415 \mathrm{~nm}$. Rutin was chosen as a standard and the total flavonoids content was expressed as milligram RE per gram of dry extracts [35].

\section{Antimicrobial activity}

Microorganisms and substrates. Eight microorganisms were selected to determine the antimicrobial activity: Staphylococcus aureus (ATCC 25923), Micrococcus luteus (ATCC 10240), Bacillus subtilis (ATCC 6633BB), Escherichia coli (ATCC 25922), Klebsiella pneumoniae (NCIMB 
9111), Pseudomonas aeruginosa (ATCC 27853), Candida albicans (ATCC 10259) and Aspergillus niger (ATCC 16404). Substrates used for the microorganisms growth: antibiotic agar no. 1 for microbiology for bacteria and tryptic soy agar for fungi (Merck, Darmstadt, Germany).

\section{Disc-diffusion method}

The disc-diffusion method [38] was used for testing the antimicrobial activity of propylene glycol extracts of $E$. arvense, $\mathrm{S}$. officinale, Na-usniate, as well as the mixture of extracts and Na-usniate and formulated gel. The samples were dissolved in dimethyl sulfoxide (DMSO; BDH, Milan, Italy). The substrates were sterilized for 15 minutes in an autoclave at $121^{\circ} \mathrm{C}$. To $50 \mathrm{ml}$ of agar, $0.5 \mathrm{ml}$ of microorganism was added and the samples of $10 \mathrm{ml}$ each were poured to each Petri dish. Filter paper discs (12.7 mm dia., Schleicher \& Schuell) were placed on inoculated substrates and impregnated with $50 \mu \mathrm{l}(100 \mathrm{mg} / \mathrm{ml}$ for extracts and gel, $1 \mathrm{mg} / \mathrm{ml}$ for Na-usniate) of the sample. Plates were incubated for 24 hours at $37^{\circ} \mathrm{C}$ for bacteria, and 48 hours at $30^{\circ} \mathrm{C}$ for fungi. The antibacterial activity is expressed as the value of the inhibition zones $(\mathrm{mm})$ obtained by the investigated samples.

Standardized discs of ampicillin (10 $\mu \mathrm{g} / \mathrm{disc})$, amikacin (10 $\mu \mathrm{g} /$ disc), and nystatin (100 $\mathrm{U} / \mathrm{disc})$ served as positive controls. Disc impregnated with $50 \mu \mathrm{l}$ DMSO was negative control. All determinations were performed in duplicate and two positive growth controls were included.

\section{Microdilution method}

In order to investigate the antimicrobial activity (minimal inhibitory concentration - MIC) of $H$. perforatum and A. millefolium extracts, as well as Na-usniate, the modified microdilution technique was used [39]. Bacterial species were cultured overnight at $37^{\circ} \mathrm{C}$ in Luria-broth (LB) medium. The fungal spores were washed from the surface of agar plates with sterile $0.85 \%$ saline containing $0.1 \%$ Tween $80(\mathrm{v} / \mathrm{v})$. The fungal and bacterial cell suspension was adjusted with sterile saline to the concentration of approximately $1.0 \times 10^{5}$ $\mathrm{CFU} / \mathrm{ml}$ in a final volume of $100 \mu \mathrm{l}$ per well. The inocula were stored at $4{ }^{\circ} \mathrm{C}$ for further use. Dilutions of the inocula were cultured on solid $\mathrm{MH}$ for bacteria and solid MA for fungi to verify the absence of contamination and to check the validity of the inoculum.

Minimum inhibitory concentrations (MIC) determination was performed by a serial dilution technique using 96-well microtitre plates. The investigated samples were dissolved in $5 \%$ DMSO $(1 \mathrm{mg} / \mathrm{ml})$ and added in broth medium with inoculum. The microplates were incubated for $48 \mathrm{~h}$ at $37^{\circ} \mathrm{C}$ for bacteria and $72 \mathrm{~h}$ at $28^{\circ} \mathrm{C}$ for fungi. The lowest concentration without the visible growth was defined as MIC. Doxycycline and nystatin were used as positive controls [40].

\section{Results and discussion}

\section{HPLC analysis}

HPLC chromatograms of the investigated propylen glycol extracts from $H$. perforatum, $A$. millefolium, E. Arvense and $S$. officinale are shown in Figures 1 to 4 , respectively.

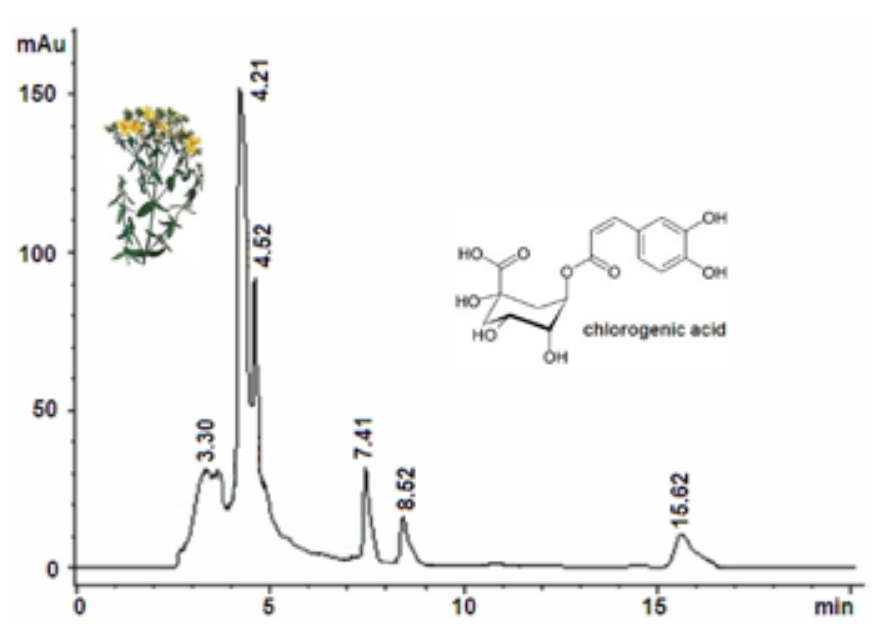

Figure 1. HPLC chromatogram of propylene glycol extract of $H$. perforatum (4.52 $\mathrm{min}$ - phenolcarboxylic acid derivatives; 7.41 min - quercetin glycoside; $15.61 \mathrm{~min}$ - apigenin glycoside)

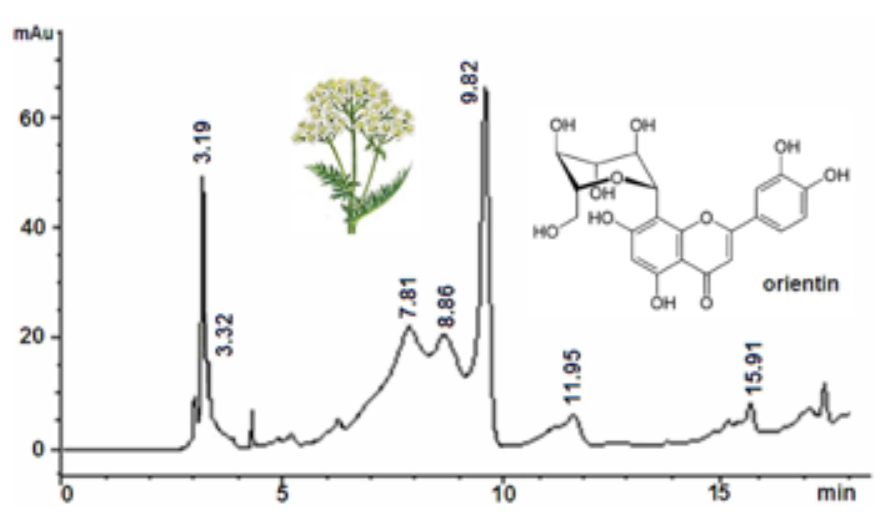

Figure 2. HPLC chromatogram of propylene glycol extract of $A$. millefolium (3.32 min - caffeic acid derivative; 7.81 min - orientin; $9.82 \mathrm{~min}$ - luteolin-7-O-glycoside; $11.95 \mathrm{~min}$ - apigenin7-O-glycoside; 15.91 min - luteolin-glycoside)

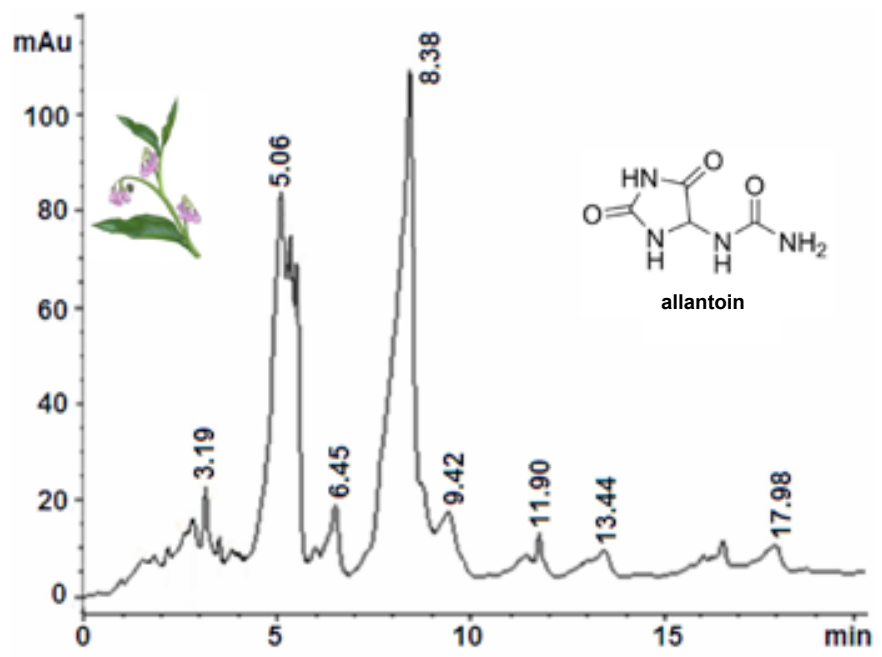

Figure 3. HPLC chromatogram of propylene glycol extract of $S$. officinale (5.06 min - caffeic acid; $8.38 \mathrm{~min}$ - chlorogenic acid; $9.42 \mathrm{~min}$ - allantoin; $13.44 \mathrm{~min}$ - luteolin-glycoside) 


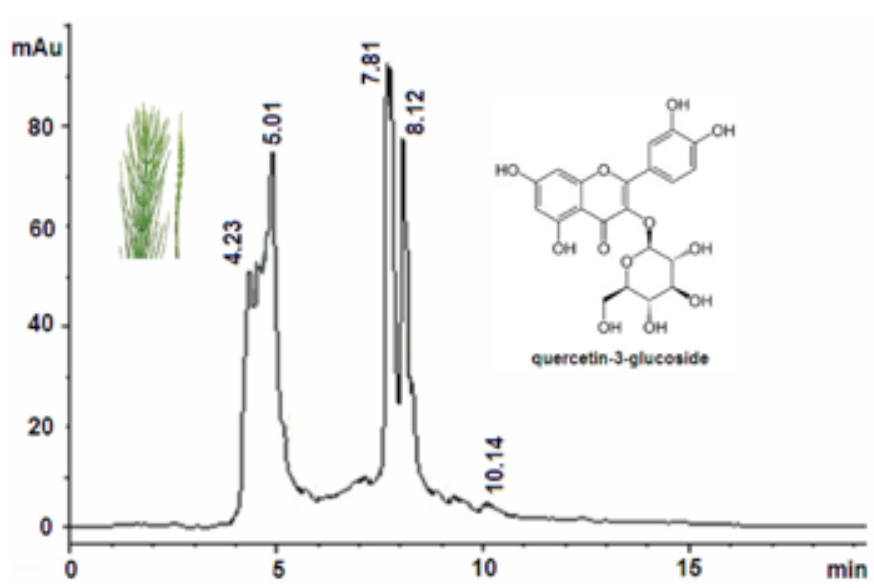

Figure 4. HPLC chromatogram of propylene glycol extract of $E$. arvense (4.23 $\mathrm{min}$ - phenolcarboxylic acid derivatives; 7.81 min - quercetin-3-O-glycoside; 8.12 min - quercetin-3-O-(6'-Omalonil)-glycoside; 10.14 min - pentacyclic triterpenoid sapo$\operatorname{nin})$

HPLC analysis of propylene glycol extracts showed the presence of the following compounds: a) phenolcarboxylic acid derivatives, as well as derivatives of quercetin and apigenin in $H$. perforatum extract; caffeic acid, quercetin glycosides and pentacyclic triterpenoid saponines in E. arvense extract; caffeic and chlorogenic acid, allantoin, luteolin glycoside in S. officinale; caffeic acid derivative, orientin, luteolin glycoside and apigenin glycoside in $A$. millefolium extract.

Based on presented results, it can be concluded that phenolic compounds (phenolic acids and flavonoids) are present in all extracts. Phenolic compounds are well known antioxidant and antimicrobial agents [5,23,24]. Allantoin, one of the components of $S$. officinale extract, has a strong pharmacological activity. Because of that, $S$. officinale extract has a wetting and keratolytic effect, increases smoothness of the skin leading to cell proliferation and wound healing, also has soothing, anti-irritating and protective effects on the skin [41].

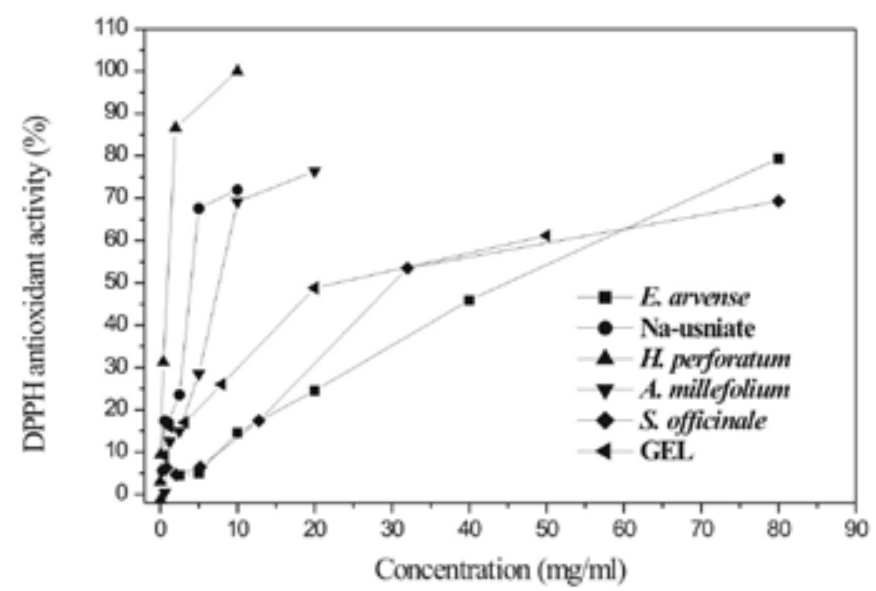

Figure 5. Antioxidant activity of $H$. perforatum (St. John's worth), A. millefolium (yarrow), S. officinale (comfrey), E. arvense (horstail), Na-usniate and gel estimated by DPPH test

\section{Antioxidant activity}

The DPPH test is based on the exchange of hydrogen atoms between antioxidants and stable DPPH free radical. Practically, the reaction is based on the reduction of DPPH radicals to the corresponding hydrazine, which is manifested by the colour change from violet to yellow, which is monitored spectrophotometrically [31,32]. The antioxidant activity of the extracts from $E$. arvense, $H$. perforatum, A. millefolium, S. officinalis, Na-usniate and formulated gel is shown in Figure 5.

The propylene glycol extracts of $H$. perforatum, $A$. millefolium, E. arvense and $S$. officinale, as well as tested Na-usniate and formulated gel, show a dose-dependent antioxidant activity in DPPH test. The $\mathrm{EC}_{50}$ value is a widely used parameter to measure the free radical scavenging activity. A lower $\mathrm{EC}_{50}$ indicates a higher antioxidant activity [42]. The antioxidant activity of the investigated samples decreases in the series: $H$. perforatum $\left(E_{50}=1.04 \mathrm{mg} / \mathrm{ml}\right)>$ Na-usnate $\left(E_{50}=4.16 \mathrm{mg} / \mathrm{mL}\right)>A$. millefolium $\left(\mathrm{EC}_{50}=7.60 \mathrm{mg} / \mathrm{ml}\right)>$ gel $\left(\mathrm{EC}_{50}=23.47 \mathrm{mg} / \mathrm{ml}\right)$ $>$ S. officinale $\left(\mathrm{EC}_{50}=30.10 \mathrm{mg} / \mathrm{ml}\right)>E$. arvense $\left(\mathrm{EC}_{50}=\right.$ $44.70 \mathrm{mg} / \mathrm{ml}$ ). Each value is a mean value of three measurements. The $\mathrm{EC}_{50}$ values, the amount of total phenolic and flavonoids for all extracts are given in Table 1.

In all investigated extracts (Figures 1-4) the presence of phenolic components (mainly phenolic acids and flavonoids) was determined, which is attributed a major role in the antioxidant activity of the plant extracts [43]. Since the antioxidant activity of the investigated extracts does not originate from phenolic compounds only, it is probably due to synergic action of these compounds with other biomolecules isolated from the plant material.

The extract of $H$. perforatum showed the highest while $S$. officinale extract showed the lowest antioxidant activity (Table 1 and Figure 1). The gel, as a formulation which contains all investigated extracts and Na-usniate, showed the antioxidant activity between these opposite values, which was expected.

In general, the samples with a high antioxidant activity showed a high phenolic content [42].

BHT concentration necessary for reaching $\mathrm{EC}_{50}$ in DPPH test after 20 minutes of incubation was $0.021 \mathrm{mg} / \mathrm{ml}$ (Table 1). The obtained data showed that all investigated extracts had or possessed lower antioxidant activities than BHT standard.

The results in Table 1 show that the extract of $H$. perforatum has a high phenolic content. This extract showed the best antioxidant activity, which probably comes from the high content of phenolic compounds in the extract.

The presence of hydroxyl group in phenolic compounds is probably the main factor for their antioxidant activity. Namely, phenolic compounds give stable aroxy radical by releasing $\mathrm{H}$-atoms from $\mathrm{OH}$-groups. The stable aroxy radicals react with other radicals (with DPPH, among others) and produce new stable compounds. So this is probably a mechanism through which phenolic compounds from the extracts exhibit their antioxidant activity [44]. 
Table 1. $E_{50}$ values, total phenolic and flavonoids for all investigated samples

\begin{tabular}{llll}
\hline Sample & $\begin{array}{l}\text { Total phenolic content } \\
\text { mgGAE/1g of extract }\end{array}$ & $\begin{array}{l}\text { Total flavonoids, } \mathbf{~ m g} \\
\text { RE/1 } \mathbf{~ g} \text { of extract }\end{array}$ & $\begin{array}{c}\mathrm{EC}_{50} \\
(\mathbf{m g} / \mathbf{m l})\end{array}$ \\
\hline S. officinale extract & 0.36 & 0.83 & 30.10 \\
E. arvense extract & 1.43 & 0.27 & 44.70 \\
A. millefolium extract & 4.43 & 0.44 & 7.60 \\
H. perforatum extract & 16.45 & 0.13 & 1.04 \\
Na-usniate & & & 4.16 \\
Gel & 1.35 & 0.66 & 23.47 \\
BHT & & & 0.021 \\
\hline
\end{tabular}

The results suggest that formulated phyto-gel may be used in topical formulations in order to protect the skin from damage caused by free radicals and reactive oxygen species.

Antimicrobial activity

The results of antimicrobial activity determinations of the investigated extracts are shown in Tables 2 and 3 . Microdilution assay was used for the determination of the minimal inhibitory concentration (MIC) for $H$. perforatum and $A$. millefolium extracts, as well as for $\mathrm{Na}$-usniate (Table 2), and the agar diffusion method was used for antimicrobial properties of $S$. officinale and $E$. arvense extracts determination (Table 3).

Table 2. Minimal inhibitory concentration of Na-usniate, $H$. perforatum extract and $A$. millefolium extract

\begin{tabular}{|c|c|c|c|c|c|c|c|c|}
\hline Samples & S. a. & $\begin{array}{c}M . I . \\
2\end{array}$ & $\begin{array}{c}\text { B.s. } \\
3\end{array}$ & $\begin{array}{c}\text { E.c. } \\
4\end{array}$ & $\begin{array}{c}\text { K.p. } \\
5\end{array}$ & $\begin{array}{l}\text { P.a. } \\
6\end{array}$ & $\begin{array}{c}\text { C.a1. } \\
7\end{array}$ & $\begin{array}{c}\text { A.n. } \\
8\end{array}$ \\
\hline Na-usniate $(\mathrm{mg} / \mathrm{ml})$ & 0.78 & 1.18 & 0.58 & 1.22 & 1.36 & 4.68 & 37.51 & 18.78 \\
\hline $\begin{array}{l}\text { H. perforatum extract } \\
(\mathrm{mg} / \mathrm{ml})\end{array}$ & 7.23 & 7.81 & 7.25 & 7.55 & 15.6 & 7.53 & 115 & 98.63 \\
\hline $\begin{array}{l}\text { A. millefolium extract } \\
(\mathrm{mg} / \mathrm{ml})\end{array}$ & 7.85 & 7.85 & 7.81 & 7.81 & 15.6 & 15.6 & 450 & 230 \\
\hline Doxycycline $(\mu \mathrm{g} / \mathrm{ml})$ & 0.81 & nt. & 1.56 & 0.84 & nt. & 11.45 & nt. & nt. \\
\hline Nystatin ( $\mu \mathrm{g} / \mathrm{ml})$ & nt. & nt. & nt. & nt. & nt. & nt. & 6.55 & 6.55 \\
\hline
\end{tabular}

Table 3. Inhibition zone of $S$. officinale and $E$. arvense extracts, Na-usniate and gel

\begin{tabular}{|c|c|c|c|c|c|c|c|c|}
\hline \multirow[b]{2}{*}{ Microorganism } & \multicolumn{8}{|c|}{ The inhibition zone $(\mathrm{mm})$} \\
\hline & $\begin{array}{l}\text { S. } \\
\text { officinale }\end{array}$ & $\begin{array}{l}\text { E. } \\
\text { arvense }\end{array}$ & $\begin{array}{l}\mathrm{Na}- \\
\text { usniat } \\
\text { e }\end{array}$ & $\begin{array}{l}\text { Gel } \\
\text { with } \\
\mathrm{Na}- \\
\text { usniat } \\
\text { e }\end{array}$ & $\begin{array}{l}\text { Gel } \\
\text { without } \\
\text { Na- } \\
\text { usniate }\end{array}$ & Amikacin & Ampicillin & Nystatin \\
\hline S. aureus & 15.8 & 12.7 & 24.1 & 25.8 & 24.6 & 25.2 & 26.1 & nt. \\
\hline B. subtilis & 13.2 & 11.5 & 27.4 & 27.1 & 26.3 & 32.1 & 15.2 & nt. \\
\hline M. luteus & - & 26.3 & 22.4 & 25.0 & 21.5 & 31.2 & 32.4 & nt. \\
\hline E. coli & 15.1 & 12.5 & 21.2 & 19.1 & 15.1 & 30.0 & 18.3 & nt. \\
\hline K. pneumoniae & 17.2 & 20.1 & 20.0 & 15.7 & 12.3 & 25.5 & 23.4 & nt. \\
\hline$P$. aeruginosa & - & 11.3 & 18.1 & 24.1 & 22.5 & 30.5 & nt. & nt. \\
\hline C. albicans & - & 17.5 & 14.5 & 15.2 & 12.5 & nt. & nt. & 21.7 \\
\hline A. niger & - & 17.1 & 15.1 & 15.2 & 13.1 & nt. & nt. & 22.2 \\
\hline
\end{tabular}


According to the results shown in Table 2, it can be concluded that $\mathrm{Na}$-usniate has the highest antimicrobial activity, while $H$. perforatum and $A$. millefolium extracts are weaker antimicrobial agents. Based on the inhibition zone diameter of $S$. officinale and $E$. arvense extracts (Table 3), it can be concluded that $E$. arvense extract has the effect on all tested microorganisms, but the highest effect was manifested on $M$. luteus microorganism. The antimicrobial activity of the formulated gel (with or without Na-usniate) and pure Na-usniate is shown in Table 3. Based on these results, it can be concluded that $\mathrm{Na}$ usniate is mostly responsible for the gel antimicrobial activity, because Na-usniate itself shows a relatively strong antimicrobial activity. The activity of the formulated gel is also enhanced by the extracts which enter into its composition.

Our results are in accordance with the previously described. Candan and coworkers tested the antimicrobial and antioxidant activity of $A$. millefolium essential oil and the methanol extract [1]. The essential oil was more active than the methanol extract, with a very high antioxidant and weak antimicrobial activity. Conforti and coworkers [45] tested methanolic extracts of $H$. perforatum, and Ma \& Xiao [46] showed a correlation between the antioxidant activity of $H$. perforatum and distribution of flavonoids in stems, leaves and flowers. The propylene glycol extract of $H$. perforatum had the highest antioxidant activity among the tested extracts with $\mathrm{EC}_{50}=1.04 \mathrm{mg} / \mathrm{ml}$. Bioguided fractionation led to flavonoids quercetin and biapigenin, responsible for a weak antimicrobial activity, while the recent research showed the antimicrobial activity of hypericin comparable to standard antibiotics which was not detected in our extract [28].

A recent publication about the antioxidant activity of $E$. arvense extracts showed a high DPPH $\left(E_{50}=0.65 \mathrm{mg} /\right.$ $\mathrm{ml})$ and hydroxyl radical scavenging $(E C=0.74 \mathrm{mg} / \mathrm{ml})$ activity of $n$-butanol extract which was correlated with the total phenolic content. Ethylacetate, $n$-butanol and water extracts possessed a weak antibacterial activity against $P$. aeruginosa, $S$. aureus and $B$. cereus [27].

Formulated phyto-gel can find potential application as a natural antiseptic and antioxidant for topical use. Thanks to the presence of different extracts, this phytogel can find a potential application in a variety of skin diseases such as acne and eczema (due to the presence of the horsetail extract) [27], skin inflammation, wounds, purulent processes (due to the presence of the yarrow extract) [47], skin burns and wound infections (due to the presence of $H$. perforatum extract) [19], skin regeneration [48] and a antirheumatic agent (S. officinale extract) [49]. Usnic acid and its salts have well known antioxidant and antimicrobial properties [29,30], so Na-usniate is also an important component of the investigated phytogel in terms of the antioxidant and antimicrobial activity.

\section{Conclusion}

New generation phyto-gel was made of four plant extracts incorporated $(H$. perforatum, A. millefolium, $E$. arvense and $S$. officinale extract), as well as Na-usniate. The formulated herbal gel showed antioxidant and antimicrobial properties. $H$. perforatum extract is the most responsible component of phyto-gel in terms of the antioxidative activity, while the presence of Na-usniate is most responsible for the antimicrobial activity. The antioxidant and antimicrobial activity of the gel is probably a result of a synergistic effect of all components. New generation phyto-gel formulated from plant extracts by this method could potentially find application as a natural antioxidant and antiseptic agent for dermal use.

\section{Acknowledgements}

This research is part of the Project TR-34012 which is supported by the Ministry of Education, Science and Technological Development of the Republic of Serbia.

\section{References}

[1] F. Candan, M. Unlu, B. Tepe, D. Daferera, M. Polissiou, A. Sökmen, H. Akpulat, Antioxidant and antimicrobial activity of the essential oil and methanol extracts of Achillea millefolium subsp. millefolium Afan. (Asteraceae), Journal of Ethnopharmacology, 87 (2003) 215-220.

[2] K. X. Zhu, C. X. Lian, X. N. Guo, W. Peng, H. M. Zhou, Antioxidant activities and total phenolic contents of various extracts from defatted wheat germ, Food Chemistry,126 (2011) 1122-1126.

[3] Z. Spacil, L. Novakova, P. Solich, Analysis of phenolic compounds by high performance liquid chromatography and ultra performance liquid chromatography, Talanta, 76 (2008) 189-199.

[4] K. Haila, Effects of carotenoids and carotenoid-tocopherol interaction on lipid oxidation in vitro, Thesis, University of Helsinki, Helsinki, 1999.

[5] L. R. Fukumoto, G. Mazza,Assessing, antioxidant and prooxidant activities of phenolic compounds, Journal of Agricultural and Food Chemistry, 48 (2000) 3597-35604.

[6] D. D. Kitts, An evaluation of the multiple effects of the antioxidant vitamins, Trends in Food Science \& Technology,8(1997) 198-203.

[7] J. Wall, Antioxidants in prevention ofreperfusion damage of vascularendothelium,Pharmacology, 1 (2000) 67-71.

[8] R. Aquino, S. Morelli, A. Tomaino, M. Pellegrino, A. Saija, L. Grumetto, C. Puglia, D. Ventura, F. Bonina, L. Grumetto, Antioxidant and photoprotective activity of a crude extract of Culcitium reflexum H. B. K. Leaves and their major flavonoids, Journal of Ethnopharmacology,79(2002) 183191.

[9] B. A. Silva, J. O. Malva, A. C. P. Dias, St. John's Wort (Hypericum perforatum) extracts and isolated phenolic compounds are effective antioxidants in several in vitro models of oxidative stress, Food Chemistry, 110 (2008) 611-619.

[10] N. Ito, S. Fukushina, H. Tsuda, Carcinogenicity and modification of the carcinogenic response by BHA, BHT and other antioxidants, CRC Critical Review in Toxicology, 15 (1985) 109-115.

[11] J. M. Čanadanovic-Brunet, S. M. Djilas, G. S. Ćetković, V. T. Tumbas, A. I. Mandić, V. M. Čanadanović, 
Antioxidant activities of different Teucrium montanum L. extracts, International Journal of Food Science \& Technology, 41 (2006) 667-673.

[12] S. M. Djilas, J. M. Canadanovic-Brunet, G. S. Cetkovic, V. T. Tumbas, Antioxidative activity of some herbs and species - review of ESR studies, In P. S. Gill, A. M. Webb, G. A. RutledgeEds., Magnetic resonance in Food Science, Belton, Cambridge, 2003, pp. 110-120.

[13] A. Nostro, M. P. Germanò, V. D'Angelo, A. Marino, M. A. Cannetelli, Extraction methods and bioautography for evaluetion of medicinal plant antimicrobial activity, Letters in Applied Microbiology, 30 (2000) 379-384.

[14] P. Marimuthu, C.-L. Wu, H.-T. Chang, S.-T. Chang, Antioxidant activity of the ethanolic extract from the bark of Chamaecyparisobtusa var. Formosana, Journal of the Science of Food and Agriculture, 88 (2008) 1400-1405.

[15] C. Proestos, I.S. Boziaris, G.-J.E. Nychas, M. Komaitis, Analysis of flavonoids and phenolic acids in Greek aromatic plants: Investigation of their antioxidant capacity and antimicrobial activity, Food Chemistry, 95(2006) 664671.

[16] C. Papadopoulou, K. Soulti, I. G. Roussis, Potential antimicrobial activity of red and white wine phenolic extracts against strains of Staphylococcus aureus, Escherichia coli and Candida albicans,Food Technology and Biotechnology,43(2005) 41-46.

[17] L. C. Obame, J. Koudou, B. S. Kumulungui, I. H. N. Bassolé, P. Edou, A. S. Ouattara, A. S.Traoré, Antioxidant and antimicrobial activities of Canarium schweinfurthii Engl. Essential oil from Centrafrican Republic, African Journal of Biotechnology, 6(2007) 2319-2323.

[18] A. Basile, S. Sorbo, V. Spadaro, M. Bruno, A. Maggio, N. Faraone, S. Rosselli, Antimicrobial and antioxidant activities of coumarins from the roots of Ferulago campestris (Apiaceae), Molecules, 14 (2009) 939-952.

[19] Z. Saddiqe, I. Naeem, A. Maimoona, A review of the antibacterial activity of Hypericum perforatum L, Journal of Ethnopharmacology, 131 (2010) 511-521.

[20] M. C. Recio, J. L. Ríos, A. Villar, A review of some antimicrobial compounds isolated from medicinal plants reported in the literature 1978-1988, Phytotheraphy Research, 3 (1989) 117-125.

[21] J. P. Rauha, S. Remes, M. Heinonen, A. Hopia, M. Kahkonen, T. Kujala, K. Pihlaja H. Vuorela, P. Vuorela, Antimicrobial effects of Finnish plant extracts containing flavonoids and other phenolic compounds, International Journal of Food Microbiology, 56 (2000) 3-12.

[22] G. Bisignano, A. Tomaino, R. Lo Cascio, G. Crisafi, N. Uccella, A. Saija, On the in vitro antimicrobial activity of oleuropein and hydroxytyrosol, Journal of Pharmacy and Pharmacology, 51(1999) 971-974.

[23] M. M. Y. Chan, Antimicrobial effect of resveratrol on dermatophytes and bacterial pathogens of the skin, Biochemical Pharmacology,63 (2002) 99-104.

[24] [A. M. Wen, P. Delaquis, K. Stanich, P.Toivonen, Antilisterial activity of selected phenolic acids, Food Microbiology, 20 (2003) 305-311.

[25] D. Tarle, J. Petricic, M. Kupinic, Antimicrobial activity of common comfrey (Symphytum officinale L.), Acta Pharmaceutica Jugoslavica, 32 (1982) 235-237.

[26] V. M. Di Mambro, M. J. Fonseca, Assays of physical stability and antioxidant activity of a topical formulation added with different plant extracts, Journal of Pharmaceutical and Biomedical Analysis, 37 (2005) 287-295.
[27] J. M. Čanadanović-Brunet, G. S. Ćetković, S. M. Djilas, V. T. Tumbas, S. S. Savatović, A. I. Mandić, S. L. Markov, D. D. Cvetković, Radical scavenging and antimicrobial activity of horsetail (Equisetum arvense L.) extracts, International Journal of Food Science \& Technology,44(2008) 269-278.

[28] A. Karioti, A.R. Bilia, Hypericins as Potential Leads for New Therapeutics, International Journal of Molecular Sciences, 11 (2010) 562-594.

[29] F. Odabasoglu, A. Cakir, H. Suleyman, A. Aslan, Y. Bayir M. Halici, C. Kazaz, Gastroprotective and antioxidant effects of usnic acid on indomethacin-induced gastric ulcer in rats, Journal of Ethnopharmacology, 103(2006) 59-65.

[30] N. K. Honda, F. R. Pavan, R. G. Coelho, S. R. de Andrade Leite, A. C. Micheletti, T. I. B. Lopes, M. Y. Misutsu, A. Beatriz, R. L. Brum, C. Q. F. Leite, Antimycobacterial activity of lichen substances, Phytomedicine, 17(2010) 328-332.

[31] W. C. Choi, C. S. Kim, S. S. Hwang, K. B. Choi, J. H. Ahn, Y. M. Lee, H. S. Park, K. S. Kim, Y. M. Lee, Antioxidant activity and free radical scavenging capacity between Korean medicinal plants and flavonoids by assay-guided comparison, Plant Science, 163 (2002) 1161-1168.

[32] C. Sanchez-Moreno, Methods Used to Evaluate the Free Radical Scavenging Activity in Foods and Biological Systems, Food Science and Technology International, 8 (2002) 121-137.

[33] Li-C. Lu, Y-W. C. Chen, C-C. Chou, Antibacterial and DPPH Free Radical-scavenging Activities of the Ethanol Extract of propolis Collected in Taiwan, Journal of Food and Drug Analysis, 11 (2003) 277-282.

[34] D. Cvetković, D. Marković, UV-effects on antioxidant activity of selected carotenoids in the presence of lecithin estimated by DPPH test, Journal of the Serbian Chemical Society, 73(2008) 1051-1061.

[35] Lj. Stanojević, M. Stanković, V. Nikolić, Lj. Nikolić, D. Ristić J. Čanadanovic-Brunet, V. Tumbas, Antioxidant activity and total phenolic and flavonoid contents of Hieracium pilosella L. extracts, Sensors, 9 (2009) 5702-5714.

[36] V. L. Singleton, J. A. Rossi, Colorimerty of total phenolics with phosphomolybdic-phosphotungstic acid reagents, American Journal of Enology and Viticulture, 16 (1965) 144-158.

[37] J-Y. Lin, C-Y. Tang, Determination of total phenolic and flavonoid contents in selected fruits and vegetables, as well as their stimulatory effects on mouse splenocyte proliferation, Food Chemistry, 101(2007) 140-147.

[38] J.F. Acar, F.W. Goldstein, Disc susceptibility test, In Antibiotics in laboratory medicine, V. LorianEd., Baltimore, London, Los Angeles, Sydney, Williams \& Wilkins, 1996, pp. 1-52.

[39] H. Hanel, W. Raether, A more sophisticated method of determining the fungicidal effect of water-insoluble preparations with a cell harvester, using miconazole as an example, Mycoses,31(1998) 148-154

[40] D. Ilić, V. Nikolić, A. Ćirić, M. Soković, T. Stanojković, T. Kundaković, M. Stanković, Lj. Nikolić, Cytotoxicity and antimicrobial activity of allicin and its transformation products, Journal of Medicinal Plants Research,6(2012) 59-65.

[41] H. Koehler, G. Franz, Symphytum officinale, Beinwell Ztsch. Phytother., 8(1987) 166-168.

[42] P. Maisuthisakul, M. Suttajit, R. Pongsawatmanit, Assessment of phenolic content and free radical- 
scavenging capacity of some Thai indigenous plants, Food Chemistry, 100(2007) 1409-1418.

[43] M. P. Kähkönen, A. I. Hopia, H. J. Vuorela, J-P. Rauha K. Pihlaja, T. S. Kujala, M. Heinonen, Antioxidant activity of plant extracts containing phenolic compounds, Journal of Agricultural and Food Chemistry, 47(1999) 3954-3962.

[44] T. Kurechi, N. Aizawa, A. Kunugi, Studies of the antioxidants. XVIII. Oxidation products of TBHQ, Journal of the American Oil Chemists Society, 60(1983) 18781882.

[45] F. Conforti, G. A. Statti, R. Tundis, A. Bianchi, C. Agrimonti, G. Sacchetti, E. Andreotti, F. Menichini, F. Poli, Comparative chemical composition and variability of biological activity of methanolic extracts from Hypericum perforatum L., Natural Product Research, 19(2005) 295303.
[46] X. J. Ma, P. G. Xiao, Advance on the research of Hypericum perforatum, World Phytomedicines,5(1990) 150-154.

[47] G. Stojanovic, N. Radulovic, T. Hashimoto, R. Palic, In vitro antimicrobial activity of extracts of four Achillea species: The composition of Achillea clavennae L. (Asteraceae) extract, Journal of Ethnopharmacology, 101(2005) 185190.

[48] A. De Natale, A. Pollio, Plants species in the folk medicine of Montecorvino Rovella (inland Campania, Italy),Journal of Ethnopharmacology,109(2007) 295-303.

[49] M. Adams, C. Berset, M. Kessler, M. Hamburgera, Medicinal herbs for the treatment of rheumatic disorders - A survey of European herbals from the 16th and 17th century, Journal of Ethnopharmacology,121(2009) 343359.

\section{Izvod}

\section{ANTIOKSIDATIVNA I ANTIMIKROBNA AKTIVOST FITOGELA NOVIJE GENERACIJE}

Dragan J. Cvetković1 ${ }^{1}$ Ljiljana P. Stanojević ${ }^{1}$, Tatjana Kundaković ${ }^{2}$, Saša Ž. Zlatković ${ }^{1}$ Goran S. Nikolić ${ }^{1}$

${ }^{1}$ Tehnološki fakultet, Univerzitet u Nišu, Leskovac, Srbija

${ }^{2}$ Farmaceutski fakultet, Univerzitet u Beogradu, Beograd, Srbija

$\mathrm{U}$ radu je ispitivana antioksidativna i antimikrobna aktivnost fitogela - formulacija gela sa propilen-glikolnim ekstraktima $H$. perforatum, $S$. officinale, A. millefolium, E. arvense i Na-usninatom. Primenom DPPH testa određena je antioksidativna aktivnost svih ispitivanih ekstrakata, Na-usninata i gela. Primenom spektrofotometrijskih metoda određen je sadržaj ukupnih fenola i flavonoida u ekstraktima i formulisanom gelu. Antimikrobna aktivnost gela, kao i njegovih pojedinačnih komponenata, je ispitivana in vitro na sledećim mikroorganizmima: Staphylococcus aureus, Micrococcus luteus, Bacillus subtilis, Escherichia coli, Klebsiella pneumoniae, Pseudomonas aeruginosa, Candida albicans i Aspergillus niger. Antioksidativna aktivnost ispitivanih uzoraka opada u nizu: $H$. perforatum $\left(E C_{50}=1,04\right.$ $\mathrm{mg} / \mathrm{ml})>$ Na-usnate $\left(\mathrm{EC}_{50}=4,16 \mathrm{mg} / \mathrm{ml}\right)>$ A. millefolium $\left(\mathrm{EC}_{50}=7,60 \mathrm{mg} / \mathrm{ml}\right)>$ gel $\left(E C_{50}=23,47 \mathrm{mg} / \mathrm{ml}\right)>S$. officinale $\left(E_{50}=30,10 \mathrm{mg} / \mathrm{ml}\right)>E$. arvense $\left(E_{50} 44,70\right.$ $\mathrm{mg} / \mathrm{ml})$. Formulisani fitogel je pokazao $\mathrm{i}$ antimikrobnu aktivnost. Dobijeni rezultati pokazuju da ispitivani fitogel predstavlja izvor prirodnih antioksidanasa i antimikrobnih agenasa, sa mogućom primenom u farmaceutsko-kozmetičkoj industriji kao alternativa sintetičkim proizvodima.
(ORIGINALNI NAUČNI RAD)

UDK 615.454.1:615.322

Ključne reči: antioksidantna aktivnost, antimikrobna aktivnost, fitogel, biljni ekstrakti, Na-usninat 